\title{
Medical examination of detainees in Catalonia, Spain, carried out in the presence of police officers
}

\author{
Carme Vivancos Sánchez*, Iñaki Rivera Beiras**
}

\section{Key points of interest}

- Medical examinations of detainees must respect the principles of the Istanbul Protocol, and with no exceptions be carried out of the presence of detention authorities.

\begin{abstract}
Introduction: On 14th October 2019, the Supreme Court of Spain issued a court judgment convicting social and political leaders in Catalonia, of crimes of embezzlement, sedition and disobedience. Following this, widespread protests in Catalonia began. During these protests, there were also numerous clashes between protesters and members of different Catalan and Spanish police forces, which ended with more than 600 people suffering injuries to varying degrees.

Method: Semi-structured interviews in prison $(n=22)$ with people injured and detained during demonstrations.
\end{abstract}

*) Sistema de Registre i Comunicació de Violència Instituciona (SIRECOVI). Barcelona.

$\star \star)$ Observatorio del Sistema Penal y los Derechos Humanos (OSPDH). Barcelona University Correspondence to: rivera@ub.edu
Results: No detainees were informed of their right to a medical examination. $50 \%$ of detainees reported access to medical examinations in police custody. In all cases this was carried out in primary healthcare centres in the presence of police in the examination room. In all cases the report was given to the police instead of the detainee. The whereabouts of this documentation is unknown despite attempts from the detainees and their lawyers to obtain them. $31 \%$ of detainees reported being medically examined in the courthouse, with police presence at all examinations. Finally, all detainees reported routine medical examinations at the entrance to prison for pre-trial detention, none of which were carried out in the presence of police forces. Detainees reported good treatment once in the prison.

Conclusion: The results show a serious breach of regional, national and international, regulations and in particular the Istanbul Protocol principles relating to the medical examination of detainees.

Keywords: Catalan independence movement, medical examinations, police, institutional violence.

\section{Introduction}

The Catalan non-violent independence movement has undoubtedly shaped today's social and political agenda in the Spanish State. For 
many years, the operation of the Spanish political, judicial and social system was clearly marked by the existence of the separatist group, Euskadi Ta Askatasuna (hereinafter ETA). Its disarmament in 2011 ETA (Gallego, 2017) characterised a shift of focus to the Catalan pacifist independence movement.

The Catalan self-determination movement has been gaining strength in recent years, and in particular, during the referendum that took place on 1 October 2017. In a civic movement never before seen in Spain, more than 2.3 million people $(43 \%$ of the Catalan electorate) voted, despite massive police and military intervention in an attempt to deter the electorate. $92 \%$ of voters supported independence (Jones \& Burgen, 2017). More than 1000 individuals were injured by Spanish police when trying either to vote or to preserve the integrity of the ballot boxes (Generalitat de Catalunya, 2017). This resulted in the beginning of a process of political, economic and civic repression (Palou, 2017).

As part of the country's legal strategy against the pacifist movement, on $14^{\text {th }}$ October 2019, the Supreme Court of Spain issued a judgment convicting the main Catalan social and political leaders to sentences ranging from one year and eight months to thirteen years, for crimes of embezzlement, sedition and disobedience $(459 / 2019,2019)$. The weeks that followed the sentencing saw widespread social protests including mass demonstrations and a general strike. There were also numerous clashes between protesters and members of different Catalan and Spanish police forces, which ended with more than 200 people detained and approximately 600 people with varying degrees of injury, which ranged from superficial injuries to loss of eyes due to rubber bullets. Alleged injuries to 289 police officers were also reported (Garcia, 2019).
The SIRECOVI is a Documentation and Communication System for Institutional Violence $^{1}$ that collects data of ill-treatment and torture. As part of its activities, SIRECOVI has monitored detention conditions in Catalonia. The results of the research described here are part of a bigger report (SIRECOVI, 2019) that encompasses the entire process of deprivation of liberty, including arrest in public spaces, transportation, conditions in police stations and judicial courts, respect of due process in courts, and the initial days in prisons.

The study focuses on injured detainees that were transferred to Court and sent to pre-trial detention.

\section{Methods}

From $28^{\text {th }}$ October 2019, members of the SIRECOVI travelled to 6 penitentiary centers in the provinces of Barcelona, Tarragona, Lleida and Girona. In-depth interviews were carried out with individuals in pre-trial detention $(n=22)$. Initial contact was facilitated by the prisoners' lawyers. The process was complex and lengthy, requiring 3 weeks to arrange informed consent from all detainees and to plan the agenda of visits.

Ethical concerns: Participants signed an informed consent document in advance of the interviews. Special care was taken to ensure that the recollection of episodes of violence or other types of abuse did not add to the nar-

1 SIRECOVI is a Documentation and Communication System for the protection of victims of Institutional Violence. This system is put into operation when someone communicates about a person who has allegedly suffered illtreatment or torture in places of deprivation of liberty (for example prisons or police stations) or in the public space by an agent of the authority. SIRECOVI's website: https://sirecovi.ub.edu/ index_en.html 
rators' sense of victimisation. The interviews were recorded as part of the SIRECOVI database which is registered with the Catalan Data Protection Authority.

\section{Results}

In a sample of young people between 18 and 35 years old, 18 (81\%) were men and 4 were $(19 \%)$ women. $13(59 \%)$ were examined at the police station or in court. $9(41 \%)$ reported not having received any medical examination although their injuries were visually apparent. In all 22 cases, individuals were not informed of their right to a medical examination.

Police station: 11 individuals (50\%) reported that they were examined by a doctor in police detention, all in the presence of the police or security forces. All detainees were taken to a Primary Healthcare Centre (Centre d'Atenció Primària - CAP) close to their place of detention. In 2 cases (18\%) the detainees were handcuffed whilst undergoing an examination. In all 11 cases the report was given to the police instead of the detainee. The whereabouts of this documentation is unknown despite attempts from the detainees and their lawyers to obtain it.

Furthermore, the interviews revealed that the detainees had found the police presence intimidating as that they were unable to speak freely to the doctor. In particular, they were not able to discuss any ill-treatment they had endured, nor the physical and psychological consequences of the treatment. It also transpired that it was impossible to undertake a medical assessment in the two cases where the detainees remained handcuffed, despite the doctors' positive attempt at documentation.

Courtroom: $7(31 \%)$ individuals reported being examined by doctors in the courthouse. In all cases the examination was conducted in the presence of police. In 1 (14\%) case, the individual was handcuffed during examination. None of the detainees had access to the report.
Prison: All detainees reported that they were examined by doctors at the entrance of the prisons where they were to be held in pre-trial detention. Security forces were not present at any point.

The interviews highlighted the good treatment received in the prisons and that the experience was, paradoxically, one of calmness and safety that following two days of suffering, tension, ill-treatment and violence.

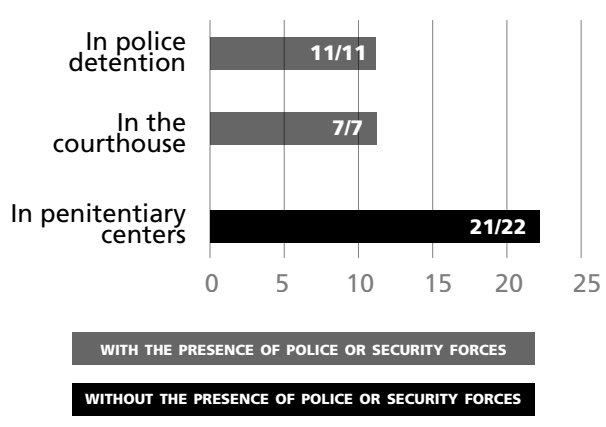

\section{Discussion}

The conduct of medical examinations of detainees is regulated by guidelines and procedures. Of particular relevance are the Istanbul Protocol at the international level and the Catalonian Charter of Citizens' Rights and Responsibilities at the sub-national level.

The Istanbul Protocol is the UN Manual on Effective Investigation and Documentation of Torture and Other Cruel, Inhuman or Degrading Treatment or Punishment. It outlines international legal standards and sets out specific guidelines on how to conduct effective legal and medical investigations into allegations of torture and ill-treatment. The relevant paragraphs of the Istanbul Protocol are:

National codes of medical ethics: IP56 "[...] to avoid harm, help the sick, protect the vulnerable and not discriminate between pa- 
tients on any basis other than the urgency of their medical needs."

IP61. "[...]doctors must always do what is best for the patient, including detainees and alleged criminals."

Established standards of medical practice: IP83 "...Medical experts involved in the investigation of torture or ill-treatment should behave at all times in conformity with the highest ethical standards and, in particular, must obtain informed consent before any examination is undertaken. The examination must conform to established standards of medical practice. In particular, examinations must be conducted in private under the control of the medical expert and outside the presence of security agents and other government officials."

84. Confidentiality. "The report should be confidential and communicated to the subject or their nominated representative."

Additionally, the Standard Minimum Rules for the Treatment of Prisoners were revised and adopted as the 'Nelson Mandela' rules. They are often regarded by states as the primary source of standards relating to treatment in detention, and are the key framework used by monitoring and inspection mechanisms in assessing the treatment of prisoners. These rules establish:

Rule 24.1. "The provision of health-care for prisoners is a state responsibility. Prisoners should enjoy the same standards of healthcare that are available in the community, and should have access to necessary health-care services free of charge..."
Rule 34. "If, in the course of examining a prisoner upon admission or providing medical care to the prisoner thereafter, health-care professionals become aware of any signs of torture or other cruel, inhuman or degrading treatment or punishment, they shall document and report such cases to the competent medical, administrative or judicial authority...'

The European Committee for the Prevention of Torture (CPT) expressed concern following its visit to Spain which took place between 6-13 September 2018:

"the delegation noted that medical examinations, whether in the police stations or at a medical centre, still took place in the presence of police officers. (...) the CPT reiterates its recommendation that steps be taken to ensure that all health care examinations are conducted out of the hearing and - unless the doctor concerned expressly requests otherwise in a given case - out of the sight of police staff" (CPT, 2020).

\section{Regulations and recommendations in Catalonia and Spain regarding medical visits}

The Charter of Citizens' Rights and Responsibilities in relation to health and healthcare sets out a regulatory procedure to follow in the doctor-patient relationship. Medical visits must be confidential and private, and the presence of anyone other than medical personnel must be expressly consented to by the patient (Generalitat de Catalunya, 2015).

Violations of the provisions of the Istanbul Protocol (among other regulatory provisions) may act to prevent detainees from giving an account of the origin of the injuries and might contribute to impunity. The Spanish Ombudsman in its 2019 report expressed concerns 
that medical examinations were carried out in places of deeprivation of liberty as well as highlighting the lack of privacy and due guarantees (Defensor del Pueblo, 2019).

\section{Conclusions}

The subject of medical examinations merits special consideration since almost all detainees interviewed reported that they were not informed of their right to a medical examination, and even being obviously injured, they either did not receive medical examinations, or where these had been carried out, police had been present in the medical units. This represents a serious breach of national and international regulations, which require that medical examinations are conducted in privacy in the sole presence of medical personnel, with no presence of the detention unit.

\section{References}

Committee for the Prevention of Torture and Inhuman or Degrading Treatment or Punishment (CPT) (2020) To the Spanish Government on the visit to Spain carried out by the European Committee for the Prevention of Torture and Inhuman or Degrading Treatment or Punishment (CPT) from 6 to 13 September 2018. https:// rm.coe.int/16809a5597

Defensor del Pueblo (2019) Informe anual 2018. Mecanismo nacional de prevención. Supervisión de lugares de privación de libertad en España, de acuerdo con el Protocolo facultativo a la Convención de las Naciones Unidas contra la tortura y otros tratos o penas crueles, inhumanas o degradantes (OPCAT). https://www.defensordelpueblo.es/wp-content/ uploads/2019/09/Informe_2018_MNP.pdf

Gallego, D. (2017) Posibles consecuencias jurídicopenales de la entrega definitiva de las armas por parte de la organización terrorista ETA [Possible criminal legal consequences of the final delivery of arms by the terrorist organisation ETA]. RJUAM, n. ${ }^{\circ} 36,2017-I I$, pp. $75-94$

García, T (28th October 2019). Detenidos de excepción $y$ heridos por balas de goma [Exceptionally detained and injured by rubber bullets]. El Salto. https:// www.elsaltodiario.com/cataluna/detenidosexcepcion-represion-protestas-balas-gomasentencia
Generalitat de Catalunya. Departament de Salut (2015) Carta de drets $i$ deures de la ciutadania en relació amb la salut i l'atenció sanitària [Charter of Rights and Duties of Citizens in Relation to Health and Health Care]. https://catsalut.gencat. cat/web/.content/minisite/catsalut/ciutadania/ drets-deures/carta-drets-deures.pdf.

Generalitat de Catalunya (2017). Informe sobre els incidents dels dies 1 al 4 d'octubre de 2017. Pacients atesos durant la joranda electoral $i$ dies posteriors a conseqüencia de les càrregues policials de l'Estat [Report on the incidents from 1 to 4 October 2017. Patients treated during election day and subsequent days as a result of state police charges]. https:// www.documentcloud.org/documents/4113650232799c8-755f-4810-ba56-0a5bbb78609c. html\#document/p3

Jones. S. \& Burgen. S. (2017, Oct 2). Catalan referendum: preliminary results show $90 \%$ in favour of independence. The Guardian. https:// www.theguardian.com/world/2017/oct/01/ dozensinjured-as-riot-police-storm-catalan-refpollingstations

Palou, J. (2017). Violación de derechos civiles y políticos. Cataluña, Septiembre y Octubre de 2017 [Violation of civil and political rights. Catalonia, September and October 2017]. Iridia. http://iridia.cat/wpcontent/ uploads/Informe-DDHH_1OCT-CAST.pdf

SIRECOVI (2019) Protocol of visits to people imprisoned since 14th October during social protests against Supreme Court ruling 459/2019. University of Barcelona. http://www.ub.edu/ospdh/sites/default/ files/documents/publicacions/sirecovi._report_ people_in_provisional_imprisonment_after_ social_protests_on_supreme_court_sentence.pdf

Supreme Court of Spain, 14 October 2019 (459/2019. Special Proceedings 20907/2017) Supreme Court of Spain. https://cdn.20m.es/ adj/2019/10/14/4019.pdf. Available in English from http://www.poderjudicial.es/cgpj/es/PoderJudicial/Noticias-Judiciales/El-Tribunal-Supremocondena-a-nueve-de-los-procesados-en-la-causaespecial-20907-2017-por-delito-de-sedicion

United Nations (1999) Istanbul Protocol. Manual on Effective Investigation and Documentation of Torture and Other Cruel, Inhuman or Degrading Treatment or Punishment. Professional Training Series No.8/Rev.1. OHCHR. https://www.ohchr.org/ Documents/Publications/training8Rev1 en.pdf

United Nations (2015) Standard Minimum Rules for the Treatment of Prisoners (The Nelson Mandela Rules). United Nations. https://undocs.org/A/ RES/70/175 